\title{
Analisis Kualitas Aplikasi OrangeHRM Menggunakan WebQual 4.0 Dalam Mempengaruhi Kepuasan Karyawan dan Produktivitas Kerja
}

\author{
Gugus Wijonarko $^{1^{*}}$, Alexander Wirapraja ${ }^{2}$ \\ ${ }^{1}$ Program Studi Ilmu Administrasi Bisnis, STIAMAK Barunawati Surabaya, Jawa Timur \\ ${ }^{2}$ Program Studi Sistem Informasi, Institut Informatika Indonesia Surabaya, Jawa Timur \\ Email: ${ }^{1 *}$ gugus.wijonarko@ stiamak.ac.id, ${ }^{2}$ awirapraja85@gmail.com
}

(Naskah masuk: 16 Jun 2021, direvisi: 5 Jul 2021, diterima: 8 Jul 2021)

\begin{abstract}
Abstrak
Sumber daya manusia merupakan aspek vital dalam pengembangan bisnis perusahaan, utamanya untuk meningkatkan layanan kepada stakeholder termasuk pelanggan, maka hal yang diperlukan terlebih dahulu adalah membenahi aspek internal. Penggunaan pencatatan secara konvensional sudah dianggap tidak relevan dengan era digital saat ini. Bilamana perusahaan ingin meningkatkan daya saingnya maka diperlukan pemanfaatan teknologi dalam operasional pekerjaan yang mereka lakukan, salah satunya adalah mengembangan peran teknologi dan informasi dalam departemen manajemen sumber daya manusia dengan menerapkan aplikasi opensource berbasis web yaitu OrangeHRM. Dalam penelitian ini dilakukan dengan pendekatan terhadap pengguna aplikasi OrangeHRM dengan mengambil sampel pengguna yang bekerja pada departemen sumber daya manusia, untuk menguji hubungan antar variabel dengan menggunakan tiga variabel yaitu kualitas website (Webqual 4.0) sebagai variabel untuk mengukur persepsi kualitas dari aplikasi OrangeHRM terhadap pengguna melalui tiga indikator, yaitu kualitas informasi, interaksi layanan dan faktor penggunaan, variabel kepuasan karyawan sebagai bentuk perasaan karyawan dalam menggunakan aplikasi dan variabel produktivitas kerja yang merupakan tingkat perubahan yang dialami oleh karyawan setelah menggunakan OrangeHRM. Metode pengukuran menggunakan analisis SEM, sedangkan pengambilan sampel penelitian dilakukan dengan metode pengambilan sampel secara purposive sampling terhadap 120 responden. Hasil yang didapatkan adalah variabel Webqual 4.0 memiliki pengaruh terhadap kepuasan karyawan dan berdampak kepada meningkatnya efektivitas dan produktivitas pekerjaan yang dilakukan di departemen sumber daya manusia perusahaan setiap responden.
\end{abstract}

Kata Kunci: Sumber Daya Manusia, SEM, Webqual 4.0, Kepuasan Karyawan, Produktivitas Kerja.

\section{OrangeHRM Application Quality Analysis Using WebQual 4.0 in Influencing Employee Satisfaction and Work Productivity}

\begin{abstract}
Human resources are a vital aspect in the development of the company's business, especially to improve services to stakeholders including customers, the first thing that is needed is to fix internal aspects. The use of conventional recording is considered irrelevant to the current digital era if the company wants to increase human resources. For its competitiveness, it is necessary to use technology in the operational work they do, one of which is to develop the role of technology and information in the human resource management department by implementing a web-based open source application, namely OrangeHRM. In this study, an approach to users of the OrangeHRM application by taking samples of users who work in the human resources department, by testing the relationship between variables using three variables, namely website quality (Webqual 4.0) as a variable to measure perceived quality of the OrangeHRM application to users through three indicators are information quality, service interaction and usage factors, employee satisfaction variable as a form of employee feeling in using the application and work productivity variable which is the level of change experienced by employees after using OrangeHRM. The measurement method uses SEM analysis, while the research sample is carried out by purposive sampling method on 120 respondents. The results obtained are the Webqual 4.0 variable has an influence on employee satisfaction and
\end{abstract}


has an impact on increasing the effectiveness and productivity of work carried out in the human resources department of each respondent's company.

Keywords: Human Resources, SEM, Webqual 4.0, Employee Satisfaction, Work Productivity.

\section{PENDAHULUAN}

Karyawan merupakan salah satu sumber daya atau aset dan modal perusahaan dalam menentukan kualitas dari pekerjaan yang dilakukan. Tingkat produktivitas karyawan yang tinggi akan memberikan dampak kinerja yang positif dalam lingkungan kerja, baik internal maupun eksternal. Produktivitas karyawan sendiri dipandang sebagai kemampuan dari seorang individu untuk mengelola masukan menjadi sebuah keluaran berdasarkan dari standar yang telah ditentukan oleh perusahaan [1]. Pemanfaatan teknologi dalam pekerjaan pun menjadi sebuah tuntutan yang harus dipenuhi oleh perusahaan untuk membuat lingkungan kerja mereka menjadi lebih efektif dan efisien, salah satunya adalah dengan memanfaatkan teknologi open source berbasis web. Penggunaan sistem informasi sumber daya manusia dianggap tepat dikarenakan implementasi sistem manual sudah dianggap tidak relevan dengan kondisi bisnis saat ini dimana terkadang dalam sistem manual banyak terdapat unsur pengambilan keputusan yang bersifat subyektivitas dan kurang dinamisnya kinerja yang dilakukan oleh karyawan serta implementasi waktu yang dirasa terlalu lama [2].

Variabel yang secara umum digunakan untuk mengukur kualitas aplikasi berbasis web adalah menggunakan Website Quality 4.0 (Webqual). Alasan mengapa webqual dipilih adalah karena variabel ini merupakan metode atau teknik pengukuran kualitas sebuah aplikasi berbasis web berdasarkan dari persepsi pengguna akhir. Variabel ini merujuk kepada pengukuran kualitas layanan sehingga variabel ini sering digunakan dalam mengevaluasi layanan teknologi informasi yang berbasis web [3]. Indikator dari variabel Webqual 4.0 terdiri dari tiga yaitu kualitas informasi, interaksi layanan, dan faktor penggunaan [4]. Indikator kegunaan adalah studi mengenai interaksi manusia dan komputer serta studi tentang kegunaan situs web tersebut, meliputi kemudahan navigasi, kesesuaian elemen desain, dan gambar atau image yang disampaikan kepada pengguna. Indikator informasi ditinjau berdasarkan studi sistem informasi secara umum. Indikator ini berkaitan dengan aspek kualitas isi dari sebuah website seperti kesesuaian informasi dengan tujuan yang diinginkan pengguna, misalnya mengenai keakuratan, format dan relevansi informasi yang disajikan didalam situs, dan indikator interaksi layanan berhubungan dengan interaksi layanan yang dirasakan oleh pengguna ketika terlibat secara mendalam pada saat mengoperasikan sebuah situs web [5].

Kepuasan Kerja secara definisi menurut Handoko tahun 2006 dalam Maulidiyah tahun 2021 [6] adalah sebuah kondisi atau keadaan dari seorang karyawan secara emosional terhadap pekerjaan yang dilakukannya baik suasana yang positif maupun negatif. Seyogyanya semakin tinggi kepuasan kerja dari seorang karyawan maka semakin tinggi pula produktivitas kerjanya. Menurut Sirajuddin tahun 2020 [7] dimensi dari kepuasan kerja pada sebuah perusahaan jasa terdiri dari lima dimensi yaitu realiability, tangible, assurance, empathy, dan responsiveness. Sedangkan dimensi dari kepuasan karyawan terkait aspek operasional dalam pekerjaan menurut Monalis tahun 2013 [8] terdapat tiga dimensi yaitu kepuasan emosional (1), kepuasan terhadap hasil kerja (2) dan kepuasan terkait persoalan dalam pekerjaan seperti promosi, gaji, supervisi dan rekan kerja (3).

Produktivitas kerja menurut Narpati tahun 2021 [9] dapat diartikan sebagai ratio output berbanding dengan ratio input. Secara umum produktivitas dapat ditentukan dari penentuan sasaran dan tujuan yang obyektif, perbandingan kerja karyawan terhadap waktu, kualitas kerja dan pengendalian hasil kerja serta pemberian fasilitas pegawai. Dimensi dari produktivitas kerja dan kinerja terdiri dari dua yaitu efektif dan efisien. Efektif yang dimaksudkan adalah pencapaian kinerja yang maksimal terkait kuantitas, faktor kualitas dan waktu. Sedangkan efisien adalah perbandingan antara masukan dengan hasil pelaksanaan pekerjannya [10]. Faktor hubungan antara kepuasan dan produktivitas ini dapat dipengaruhi dari pemanfaatan teknologi seperti implementasi Sistem Informasi Sumber Daya Manusia (SISDM). SISDM sendiri adalah sebuah sistem yang mengatur mengenai hubungan dan peran individu secara efektif dan efisien yang digunakan untuk mencapai tujuan perusahaan. Sebuah sistem memiliki prosedur yang sistematis seperti menyimpan data, mengumpulkan data, mempertahankan data, validasi data, memanggil data, dan melakukan proses pengambilan keputusan terkait aspek sumber daya manusia [11].

Pada penelitian ini mengkaji hubungan dari pemanfaatan sistem informasi sumber daya manusia menggunakan aplikasi opensource berbasis web yaitu OrangeHRM. Di Indonesia sendiri terdapat beberapa aplikasi pengelolaan sumber daya manusia selain OrangeHRM misalnya Sleekr, Talenta, BSC, Gadjian, dan lain-lain [12]. Pada penelitian ini menggunakan studi kasus pada pemanfaatan OrangeHRM karena aplikasi ini telah secara umum digunakan oleh praktisi bisnis dan telah memiliki jaringan komunitas yang besar di Indonesia serta memiliki versi yang bersifat opensource atau versi gratis, meskipun terdapat versi profesional dan enterprise yang berbayar yang ditujukan untuk kalangan profesional yang menginginkan fitur lebih lengkap [13].

OrangeHRM memiliki beberapa modul-modul yang akan sangat membantu proses administrasi departemen sumber daya manusia seperti modul admin, modul pim, modul ess, modul cuti, modul absensi dan waktu kerja, modul evaluasi 
kinerja karyawan, modul perekrutan dan lain-lain [14]. OrangeHRM sendiri merupakan aplikasi berbasis web yang dinamis karena dibuat dengan menggunakan skrip PHP. Pada OrangeHRM basis data yang digunakan adalah MySQL yang dijalankan melalui Apache Server yang dijalankan melalui paket perangkat lunak XAMPP [15].

Aplikasi sistem informasi SDM memiliki manfaat dan potensi yang menguntungkan bagi perusahaan. Sebagai contoh dua target penting dalam operasional organisasi adalah pengurangan biaya dan peningkatan efisiensi, meminimalkan penggunaan kertas, dan memaksimalkan pengiriman data dan informasi juga termasuk dalam peningkatan efektivitas dari kinerja organisasi tersebut [16]. Berdasarkan dari pemasalahan diatas maka terdapat dua rumusan penelitian pada penelitian ini meliputi:

RQ 1. Bagaimana pengaruh dari variabel WebQual 4.0 dalam mempengaruhi kepuasan dan produktivitas karyawan

RQ 2. Bagaimana hasil implementasi dari sistem informasi sumber daya manusia terhadap kinerja karyawan pada perusahaan bisnis?

\section{METODOLOGI PENELITIAN}

A. Prosedur Penelitian

Pada penelitian ini prosedur penelitian yang digunakan adalah seperti pada flowchart pada Gambar 1 berikut ini:

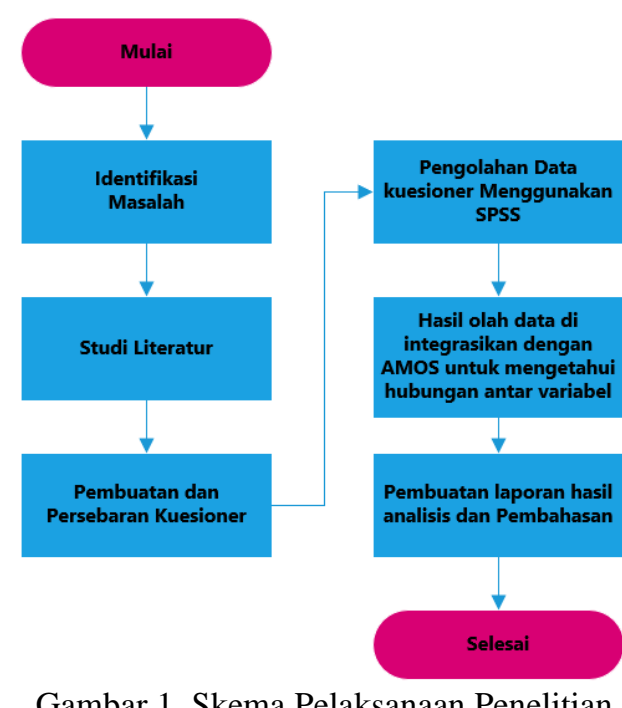

Tahapan yang dilakukan adalah mengidentifikasi dan menentukan masalah yang akan diangkat dengan mengambil cakupan masalah pada persepsi pengguna terhadap penggunaan OrangeHRM di lingkungan kerja masingmasing. Kemudian dilakukan studi literatur dengan mengambil literatur yang bersumber dari buku, majalah, website dan jurnal ilmiah, baik nasional maupun internasional. Langkah selanjutnya adalah melakukan perancangan dan penyebaran kuesioner dan didapatkan sebanyak 120 responden yang diuji keabsahannya menggunakan uji validitas dan reliabilitas menggunakan perangkat lunak SPSS dan hasil uji olah data tersebut dilakukan pemodelan menggunakan perangkat lunak AMOS untuk mendapatkan hubungan antar variabel dan dilakukan pembahasan dari hasil yang didapatkan.

\section{B. Metode Kuantitatif}

Metode kuantitatif adalah metode penelitian yang menjelaskan sebuah masalah dan hasilnya dapat digeneralisasi, sehingga keluasan data menjadi aspek penting dalam menentukan representasi dari populasi [17]. Dalam metode kuantitatif dicari hubungan sebab akibat antara setiap variabel menggunakan model pengaruh hubungan sebab akibat [18].

\section{Metode Pengambilan Sampel}

Metode Pengambilan sampel data yang digunakan pada penelitian ini menggunakan purposive sampling. Metode pengambilan ini adalah metode pengambilan sampel diambil berdasarkan keputusan peneliti untuk mencari responden yang dapat dan mau memberikan informasi berdasarkan pengetahuan dan pengalamannya. Jadi dapat diartikan bahwa responden yang dipilih dalam penelitian ini adalah pengguna yang pernah menggunakan OrangeHRM dalam aplikasi mereka. Purposive sampling juga menghasilkan sampel logis yang dianggap dapat mewakili keseluruhan dari sebuah populasi [19].

Dalam penelitian ini sampel penelitian yang digunakan sebanyak 120 responden dengan sebaran profil responden pada Tabel 1 sebagai berikut:

Tabel 1. Profil Responden

\begin{tabular}{llrr}
\hline $\begin{array}{c}\text { Profil } \\
\text { Responden }\end{array}$ & \multicolumn{1}{c}{ Kategori } & $\begin{array}{c}\text { Total } \\
\text { Responden }\end{array}$ & $\begin{array}{c}\text { Persen } \\
(\%)\end{array}$ \\
\hline Jenis & Laki-Laki & 88 & $73,3 \%$ \\
Kelamin & Perempuan & 32 & $26,7 \%$ \\
\hline Umur & $20-29$ & 46 & $38,3 \%$ \\
& $30-39$ & 47 & $39,2 \%$ \\
& 40-49 & 20 & $16,7 \%$ \\
& $>=50$ & 7 & $5,8 \%$ \\
\hline Pendidikan & S2 & 7 & $5,8 \%$ \\
& S1 & 35 & $29,2 \%$ \\
& Diploma & 41 & $34,2 \%$ \\
& SMA/SMK & 37 & $30,8 \%$ \\
\hline Jabatan & Manajer HRD & 8 & $6,7 \%$ \\
& Staf HRD & 83 & $69,2 \%$ \\
& Admin & 29 & $24,2 \%$ \\
\hline
\end{tabular}

Responden yang digunakan dalam penelitian ini adalah pengguna aplikasi OrangeHRM yang bekerja di posisi/jabatan di departemen/divisi sumber daya manusia yang terbagi dalam tiga posisi yaitu manajer HRD, staf bagian HRD, dan admin opersional.

\section{Metode Structural Equation Modelling (SEM)}

Metode SEM adalah metode yang digunakan untuk menguji koefisien model secara simultan berdasarkan hubungan antar variable. Pada metode SEM, ukuran sampel 
yang diperkenankan dalam penelitian menggunakan metode SEM adalah antara 100-300 responden [20].

E. Kerangka Penelitian

Dalam penelitian ini kerangka penelitian yang digunakan adalah seperti pada Gambar 2 berikut:

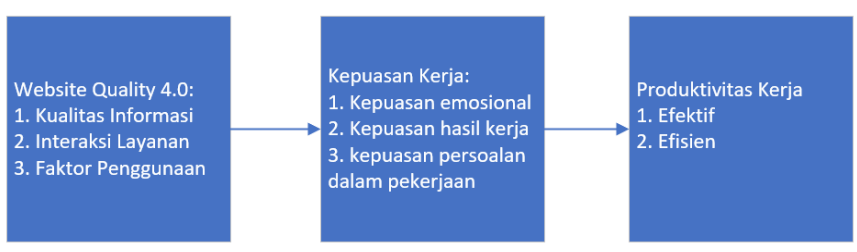

Gambar 2. Kerangka Penelitian

Dari Gambar 2 dapat dinyatakan bahwa kerangka penelitian dalam penelitian ini menggunakan 3 variabel Website Quality 4.0 dengan indikatornya yaitu kualitas informasi, interaksi layanan dan faktor penggunaan, variabel kedua yaitu variabel kepuasan kerja dengan indikator kepuasan emosional, kepuasan hasil kerja, dan kepuasan terkait persoalan dalam pekerjaan, dan variabel ketiga adalah produktivitas kerja yang diukur dari aspek efekti dan efisien. Hubungan antara ketiga variabel ini akan diukur dengan melihat antara variabel dengan indikatornya dan variabel satu dengan yang lainnya dengan mengukur tingkat persepsi dan penerimaan dan korelasi dari responden yang akan digunakan dalam penelitian ini.

\section{HASIL DAN PEMBAHASAN}

\section{A. Uji Validitas dan Reliabilitas}

Uji validitas adalah pengujian yang dilakukan terhadap butir-butir pernyataan yang terdapat dalam kuesioner yang bertujuan untuk mengukur tingkat keakuratan dari pernyataan yang terdapat dalam kuesioner/angket tersebut. Butir-butir pernyataan itu pada angket tersebut dianggap layak untuk digunakan bila memiliki korelasi signifikan terhadap skor total pernyataan. Metode validitas yang digunakan dalam penelitian ini adalah metode korelasi total item yang dikoreksi [21]. Hasil pengujian validitas kuesioner terdapat pada Tabel 2 berikut ini:

Tabel 2. Hasil Uji Validitas

\begin{tabular}{lccc}
\hline $\begin{array}{c}\text { Kode } \\
\text { Pernyataan }\end{array}$ & $\begin{array}{c}\text { Scale } \\
\text { Mean if } \\
\text { Item } \\
\text { Deleted }\end{array}$ & $\begin{array}{c}\text { Correction } \\
\text { Item-Total } \\
\text { Correlation }\end{array}$ & $\begin{array}{c}\text { Cronbach's } \\
\text { Alpha if } \\
\text { Item Deleted }\end{array}$ \\
\hline x111 & 48,13 & 0,364 & 0,814 \\
\hline x112 & 48,16 & 0,439 & 0,810 \\
\hline x121 & 48,09 & 0,433 & 0,810 \\
\hline x122 & 48,04 & 0,573 & 0,801 \\
\hline x131 & 48,07 & 0,624 & 0,799 \\
\hline x132 & 48,33 & 0,454 & 0,809 \\
\hline x211 & 47,98 & 0,387 & 0,813 \\
\hline x212 & 48,37 & 0,490 & 0,806 \\
\hline
\end{tabular}

\begin{tabular}{llll}
\hline x221 & 48,13 & 0,335 & 0,816 \\
\hline x222 & 48,34 & 0,472 & 0,808 \\
\hline x231 & 48,14 & 0,330 & 0,816 \\
\hline x232 & 48,18 & 0,144 & 0,826 \\
\hline y111 & 48,23 & 0,512 & 0,805 \\
\hline y112 & 48,32 & 0,538 & 0,805 \\
\hline y121 & 48,37 & 0,442 & 0,810 \\
\hline y122 & 48,38 & 0,282 & 0,820 \\
\hline
\end{tabular}

Hasil dari uji validitas pada Tabel 2 dengan tingkat kepercayaan $95 \%$ atau yang berarti didapatkan hasil bahwa dari 120 responden yang mengisi kuesioner didapatkan derajat kebebasan dengan melakukan perhitungan menggunakan rumus $\mathrm{df}=\mathrm{n}-2$ atau $\mathrm{df}=120-2=118$ yang dibandingkan dengan tabel $\mathrm{R}$ dengan tingkat kepercayaan sebesar $95 \%$ atau taraf signifikansi sebesar 0,05, sehingga didapatkan hasil sebesar 0,1793. Bila dibandingkan dengan kolom skor total korelasi item pada Tabel 2 sebagian besar berada di atas 0,1793 . Setelah uji validitas maka tahap selanjutnya adalah melakukan uji reliabilitas untuk mengukur apakah kuesioner tersebut dianggap stabil dan reliabel sehingga didapatkan hasil dari uji reliabilitas ditampilkan seperti pada Tabel 3 berikut ini:

Tabel 3. Hasil Uji Reliabilitas

\begin{tabular}{cc}
\hline $\begin{array}{c}\text { Cronbach's } \\
\text { Alpha }\end{array}$ & N Of Items \\
\hline 0,820 & 16 \\
\hline
\end{tabular}

Hasil dari uji reliabilitas seperti pada Tabel 3 didapatkan hasil sebesar 0,820 yang berarti kuesioner tersebut dinyatakan reliabel dan konsisten karena memiliki nilai diatas 0,70 [21].

\section{B. Analisis SEM}

Analisis dilakukan menggunakan perangkat statistik dan pemodelan yang dilakukan menggunakan analisis SEM dan didapatkan hasil seperti pada Gambar 3 dan Tabel 4 berikut ini:

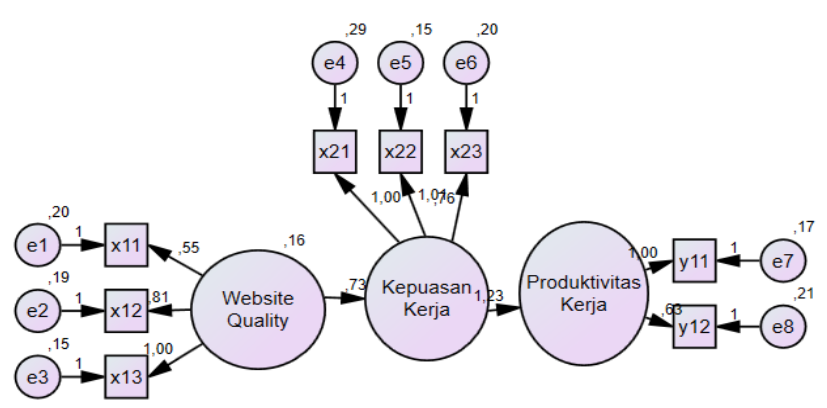

Gambar 3. Kerangka Penelitian

Dari kerangka penelitian pada Gambar 3 di atas dan dilakukan perhitungan dengan alat bantu statistik dan perangkat lunak pemodelan SEM, maka didapatkan hasil dari perhitungan analisis didapatkan hasil sebagai berikut: 
Tabel 4. Regression Weight

\begin{tabular}{lcccc}
\hline & Estimates & S.E & C.R & P \\
\hline $\begin{array}{l}\text { Kepuasan Kerja } \\
\leftarrow \text { Webqual }\end{array}$ & 0,732 & 0,158 & 4,620 & $* * *$ \\
\hline $\begin{array}{l}\text { PK } \leftarrow \\
\text { Kepuasankerja }\end{array}$ & 1,231 & 0,276 & 4,461 & $* * *$ \\
\hline $\begin{array}{l}\text { X21 } \\
\text { Kepuasankerja }\end{array}$ & 1,000 & & & \\
\hline $\begin{array}{l}\text { X22 } \leftarrow \\
\text { Kepuasankerja }\end{array}$ & 1,011 & 0,234 & 4,312 & $* * *$ \\
\hline $\begin{array}{l}\text { X23 } \leftarrow \\
\text { Kepuasankerja }\end{array}$ & 0,756 & 0,210 & 3,602 & $* * *$ \\
\hline Y11 $\leftarrow$ PK & 1,000 & & & \\
\hline Y12 $\leftarrow$ PK & 0,630 & 0,151 & 4,168 & $* * *$ \\
\hline X13 $\leftarrow$ WebQual & 1,000 & & & \\
\hline X12 $\leftarrow$ WebQual & 0,813 & 0,142 & 5,706 & $* * *$ \\
\hline X11 $\leftarrow$ WebQual & 0,551 & 0,127 & 4,337 & $* * *$ \\
\hline
\end{tabular}

Dari hasil pada Tabel 4 dapat dijelaskan bahwa loading factor seluruh hubungan antara variabel memiliki korelasi diatas 0,05 hal ini berarti hubungan antara variabel memiliki pengaruh signifikan yang tinggi antara setiap variabelnya.

Tabel 5. Standardized Regression Weight

\begin{tabular}{lr}
\hline & Estimates \\
\hline Kepuasan Kerja $\leftarrow$ Webqual & 1,000 \\
\hline PK $\leftarrow$ Kepuasankerja & 1,000 \\
\hline X21 $\leftarrow$ Kepuasankerja & 0,482 \\
\hline X22 $\leftarrow$ Kepuasankerja & 0,618 \\
\hline X23 $\leftarrow$ Kepuasankerja & 0,453 \\
\hline Y11 $\leftarrow$ PK & 0,665 \\
\hline Y12 $\leftarrow$ PK & 0,447 \\
\hline X13 $\leftarrow$ WebQual & 0,726 \\
\hline X12 $\leftarrow$ WebQual & 0,605 \\
\hline X11 $\leftarrow$ WebQual & 0,451 \\
\hline
\end{tabular}

Dari hasil pada Tabel 5 dengan tingkat kepercayaan 95\%, tingkat kepercayaan ini dipilih sebagai standar penelitian apakah data tersebut signifikan atau tidak. Kemudian dilakukan pengolahan data dari kuesioner dan hubungan antar variabel yang didapatkan hasil bahwa variabel kualitas web memiliki pengaruh terhadap kepuasan karyawan dan produktivitas kerja. Sebagai contoh pada variabel X12 yang memiliki pernyataan interaksi layanan menempati nilai tertinggi pada variabel kualitas website sehingga dapat dijelaskan bahwa karyawan merasa aman dan nyaman saat menggunakan aplikasi OrangeHRM.

Efek berkelanjutan dari pemanfaatan aplikasi tersebut adalah mereka merasa setelah menggunakan aplikasi tersebut kualitas pekerjaan mereka menjadi lebih baik. Hal ini ditunjukkan dengan nilai pada indikator X22 yaitu kualitas hasil kerja dimana menempati nilai tertinggi dari setiap indikator pada variabel kepuasan kerja, dimana karyawan merasa puas bila pekerjaan mereka bisa selesai dan kualitas pekerjaan mereka memiliki kualitas yang baik. Pada indikator Y11 atau indikator efektif yang memiliki nilai tertinggi sebesar 0,665 yang berarti para karyawan yang menjadi responden dari penelitian ini mayoritas setuju dengan memanfaatkan OrangeHRM terdapat dampak yang besar pada pekerjaan yang mereka lakukan yaitu dengan meningkatnya efektivitas dari pekerjaan yang mereka lakukan.

\section{KESIMPULAN}

Dari hasil penelitian ini maka dapat ditarik kesimpulan bahwa pemanfaatan teknologi informasi, khususnya perangkat lunak seperti OrangeHRM, akan berdampak signifikan terhadap efektivitas dari pekerjaan yang dilakukan oleh karyawan. Dengan menggunakan aplikasi perangkat lunak berbasis web mereka dapat melakukan akses dari mana saja dan kapan saja, menghemat waktu pengerjaan, membuat pekerjaan menjadi lebih cepat, dan membuat pengambilan keputusan manajerial menjadi lebih baik lagi.

\section{REFERENSI}

[1] Farozi, M. (2016). Model Perangkat Lunak Bisnis Gamifikasi Dalam Mengevaluasi Produktivitas Kinerja Kerja Karyawan. Jurnal Cendikia, Vol. 12(1), pp. 817.

[2] Saefudin \& Wahyuningsih, S. (2014). Sistem Pendukung Keputusan Untuk Penilaian Kinerja Pegawai Menggunakan Metode Analytical Hierarchy Process (AHP) Pada RSUD Serang. Jurnal Sistem Informasi, Vol. 1, pp. 33-37.

[3] Andry, J.F., Christianto, K. \& Wilujeng, F.R. (2019). Using Webqual 4.0 and Importance Performance Analysis to Evaluate E-Commerce Website. Journal of Information Systems Engineering and Business Intelligence, Vol. 5(1), pp. 23-31. DOI: 10.20473/jisebi.5.1.23-31.

[4] Sastika, W. (2016). Analisis Pengaruh Kualitas Website (WebQual 4.0) Terhadap Keputusan Pembelian pada Website e-commerce Traveloka. Seminar Nasional Teknologi Informasi dan Komunikasi (SENTIKA 2016), pp. 649-657.

[5] Ardi, A.N.A. \& Yulisetiarini, D. (2018). The Effect of Lazada Website Quality To Satisfaction and Consumer Loyalty. International Journal of Research Science \& Management, Vol. 5(10), pp. 11-15. DOI: 10.5281/zenodo.1451296.

[6] Maulidiyah, N.N., Roifah, T.N. \& Armanto, N. (2021). Kompensasi dan Kepuasan Kerja Sebagai Alternatif Peningkatan Kinerja Karyawan. Jurnal Al-Idarah, Vol. 2(1), pp. 41-48.

[7] Sirajuddin, Sari, C.A. \& Hasanuddin. (2020). Mengukur Tingkat Kepuasan Karyawan Pada Perusahaan Reparasi Mesin Industri Dengan Menggunakan Metode Importance Performance Analysis (IPA). Teknika: Jurnal Sains dan Teknologi, 
Vol. 16(1), pp. 113-121. DOI: 10.36055/tjst.v16i1.8042.

[8] Monalis, E. (2013). Pengembangan Sumber Daya Manusia dan Kinerja Karyawan. Jurnal EMBA, Vol. 1(3), pp. 1080-1088.

[9] Narpati, B., Lubis, I., Meutia, K.I. \& Ningrum, E.P. (2021). Produktivitas Kerja Pegawai yang Dipengaruhi oleh Work From Home (WFH) dan Lingkungan Kerja Selama Masa Pandemi. Jurnal Ilmu Manajemen Forkamma, Vol. 4(1), pp. 121-133.

[10] Laisa, V., Zelinsha, F. \& Monoarfa. (2018). Pengaruh Motivasi Terhadap Produktivitas Kerja Karyawan Pada PT. Primarindo Kencana (Hotel Maqna by Prasanty Gorontalo). Jurnal Ilmu Manajemen dan Bisnis Jambura, Vol. 1(2), pp. 180-190.

[11] Rosadi, A.A.S. \& Purnomo, Y.J. (2020). Pengaruh Sistem Informasi Sumber Daya Manusia Terhadap Kinerja Pada Pegawai PT Raudah Utama Cianjur. Jurnal Sains Sosio Humaniora, Vol. 4(2), pp. 357-367. DOI: 10.22437 jssh.v4i2.10865.

[12] Bernadetta. (2019). 15 Website Penyedia Aplikasi HR Terbaik Yang Wajib Dicoba. Diakses dari: https://sleekr.co/blog/15-website-penyedia-aplikasi-hrterbaik-yang-wajib-dicoba/ pada tanggal 1 Juli 2021.

[13] Agustin, F. (2014). Analisis Maturity Level Implementasi OrangeHRM Menggunakan Framework Cobit 5.0. Prosiding Seminar Nasional Informatika, pp. 51-56.

[14] Hussein, F., Kertahadi \& Riyadi. (2014). Implementasi Sistem Informasi Sumber Daya Manusia (Studi Kasus Pada Perusahaan Jasa PT . Wiranas Laundry and Dry Cleaning Service). Jurnal Admistrasi Bisnis, Vol. 10(1), pp. 1-11.

[15] Safrizal, H.B.A. (2012). Pembelajaran Manajemen
Sumber Daya Manusia Menggunakan Teknologi Open Source. Prosiding Seminas Competitive Advantage, Vol. 1(2), pp. 1-6.

[16] Subhashree, V. \& Vasantha. (2020). Influence of it Infrastructure and IT Expertise on E-HRM Adoption. International Journal of Scientific \& Technology Research, Vol. 9(1), pp. 585-589.

[17] Nugroho, A.R. (2015). Pengaruh Design Logo Baru BUMD Yang Berbasiskan Kearifan Lokal Terhadap Citra Perusahaan (Studi Kuantitatif Mengenai Perubahan Logo Baru pada PDAM Kota Bandung). Jurnal Ilmu Komunikasi Makna, Vol. 5(1), p. 1-15. DOI: $10.30659 / \mathrm{jikm} .5 .1 .1-15$.

[18] Permana, A.I. (2020). Pengaruh Kualitas Website, Kualitas Pelayanan, dan Kepercayaan Pelanggan Terhadap Minat Beli Pelanggan Di Situs Belanja Online Bukalapak. Jurnal Ekonomi Bisnis, Vol. 25(2), pp. 94-109. DOI: 10.33592/jeb.v25i2.422.

[19] Wirapraja, A., Aribowo, H. \& Setyoadi, E.T. (2021). The Influence of E-Service Quality, and Customer Satisfaction on Go-Send Customer Loyalty in Surabaya. Indonesian Journal of Information System, Vol. 3(2), pp. 128-137. DOI: 10.24002/ijis.v3i2.4191.

[20] Zuhdi, Z., Suharjo, B. \& Sumarno, H. (2016). Perbandingan Pendugaan Parameter Koefisien Struktural Model Melalui SEM dan PLS-SEM. Journal of Mathematics and Its Application, Vol. 15(2), pp. 1122. DOI: 10.29244/jmap.15.2.11-22.

[21] Chandra, W. \& Wirapraja, A. (2020). The Effect of Application Usability, Service Quality, and ESatisfaction on Purchase Intention of GoFood Customers. Indonesian Journal of Information System, Vol. 3(1), pp. 38-49. 